\title{
Tumor Protein p73
}

National Cancer Institute

\section{Source}

National Cancer Institute. Tumor Protein p73. NCI Thesaurus. Code C18577.

Tumor protein p73 (636 aa, $70 \mathrm{kDa}$ ) is encoded by the human TP73 gene. This protein is involved in the regulation of transcription, DNA damage response and apoptosis. 